Research Paper

\title{
Complexity in the governance of tourism networks: Balancing between external pressure and internal expectations
}

\author{
Egbert van der Zee ${ }^{\mathrm{a}, \mathrm{b}, *}$, Anne-Mara Gerrets ${ }^{\mathrm{a}}$, Dominique Vanneste ${ }^{\mathrm{a}}$ \\ ${ }^{a}$ KU Leuven, Division of Geography and Tourism, Celestijnenlaan 200E - Box 2409, 3001 Leuven, Belgium \\ b Utrecht University, Division of Human Geography and Planning, Heidelberglaan 2, 3584 CS, Utrecht, The Netherlands
}

\section{A R T I C L E I N F O}

\section{Keywords:}

Tourism networks

Network governance

Destination management

Stakeholder management

Trust

Power

\begin{abstract}
A B S T R A C T
Tourism destinations are complex systems of interrelated entities without a hierarchical chain of command. In order to enhance the ability of destinations to create a high quality, authentic tourism experience, a management perspective based on networks, personal relationships, trust, and reciprocity is suggested. However, while theoretically this 'network approach' represents a promising way of making the tourism industry more innovative and competitive, few convincing empirical examples have so far been published on how tourism networks can be successfully managed. This paper focuses on the gap between theory and practice. After summarizing the literature on network management in tourism, in-depth interviews with 12 network managers in Flanders (Belgium) give insights on how networks are currently managed, as well as how and why network managers choose their priorities. The main conclusion is that while all interviewed network managers claimed that they had adopted a 'network approach', most of them still spent most of their time and energy on traditional power-related tasks, such as the top-down provision of information, lobbying, and representing the network towards external stakeholders. Trust-related activities, such as actively pursuing member collaboration, member engagement, and facilitating proximity and partnerships with and between (potential) network members were only applied by a small minority. Network managers who actively strengthened the network structure through trust-related management activities indicated more often that their networks were resilient to external pressure. This highlights the importance for network managers of making pragmatic trade-offs between various management approaches. This might need further professionalization of the sector, including targeted training and (postgraduate) education.
\end{abstract}

\section{Introduction}

Tourism destinations are complex, adaptive systems of interrelated entities which are often only partially dependent on tourism (Hartman, 2016; Leiper, 1990; Pearce, 2014). Destination managers in general have limited coercive power over the manifold number of entities making up the destination and determining the tourist experience. This makes coordination and quality management by destination management organizations (DMOs) a difficult task (Beritelli, Buffa, \& Martini, 2015). DMOs are, however, currently shifting from a position of marketing destinations to attract visitors to actively managing destinations to improve the quality of the tourist experience and improve destination competitiveness (Bornhorst, Ritchie, \& Sheehan, 2010; Go \& Govers, 2000; Volgger \& Pechlaner, 2014). Many authors have suggested that in situations where a management strategy based on control or other power-based means is not possible, gaining competitive advantage should be sought through the formation of networks consisting of less-formalized relationships which are based on trust, reciprocity and inclusive governance (Bornhorst et al., 2010; Nunkoo \& Ramkissoon, 2012; Pavlovich, 2003; van der Zee \& Vanneste, 2015; Volgger \& Pechlaner, 2014). The metaphor of networks is used to suggest a management approach focusing on collaboration and stakeholder engagement without formal, contractual relationships and coercion (Provan \& Kenis, 2008).

Traditionally in tourism, neo-classical management perspectives focusing on formal, contractual relationships, hierarchy and power, or neo-liberal laissez-faire approaches to management based on competition and limited public interference have been dominant (Hall, 1999; Pearce, 2014; Porter, 1990). Recently, a network approach to destination management has become more popular, both in the literature as well as among policy makers and DMOs (van der Zee \& Vanneste, 2015). This relational approach aims to achieve collaboration and stakeholder engagement through managing relationships with and between stakeholders based on trust and reciprocity (Del

\footnotetext{
* Corresponding author at: KU Leuven, Division of Geography and Tourism, Celestijnenlaan 200E - Box 2409, 3001 Leuven, Belgium.

E-mail addresses: egbert.vanderzee@kuleuven.be (E. van der Zee), Am.gerrets@gmail.com (A.-M. Gerrets), dominique.vanneste@kuleuven.be (D. Vanneste).
} 
Chiappa \& Presenza, 2013). This change in management approach entails different roles and tasks for destination managers (Baggio, Scott, \& Cooper, 2010; Brouder \& Eriksson, 2013; Coase, 1937; Hartman, 2016; Porter, 1990). For instance, in a network approach, destination managers need to bring stakeholders together, stimulate them to sharing information, knowledge and experiences and facilitate them to developing new touristic concepts and products in order to become a more competitive destination for tourists and travelers (Beaumont \& Dredge, 2010; d'Angella \& Go， 2009; Dredge, 2006; Lemmetyinen \& Go, 2009).

In order to stimulate collaboration and to increase the commitment to work towards common goals, trust between the different stakeholders is believed to be a vital ingredient (Beritelli, 2011; Nunkoo \& Ramkissoon, 2012). This means that for networks to be effective, participants must be able to trust each other to work to their mutual benefit (Keast, Mandell, Brown, \& Woolcock, 2004). Trust is created and strengthened through repetitive interaction among stakeholders (Stein \& Harper, 2003). However, to accomplish this is easier said than done. Tourist entrepreneurs sometimes collaborate, but are also competitors which means that sharing knowledge implies risks (Novelli, Schmitz, \& Spencer, 2006). This may make entrepreneurs watchful or even reluctant to participate actively in networks. Even though tourism should be a sector in which cooperation features at the forefront of management approaches, cooperation in the tourism sector generally 'neither obviously occurs nor is formally established' (Beritelli, 2011, p. 609). This observation makes it useful to learn more about what makes network work.

While trust is both the input and output of intra-network cohesion, and therefore vital for network formation and success, this does not mean that the use of power is absent or should be absent in networks. Co-operative behavior within a network is argued to be more likely when a level of leadership is present, which distributes power and helps to 'maximize the advantages and synergies of joint action' (Zehrer, Raich, Siller, \& Tschidereret al., 2014, p.59). In other words, networks also need to be managed. In tourism, publicly funded DMOs are regarded as the most likely and legitimate party to foster network development and create trust relationships between its stakeholders (Bornhorst et al., 2010; Bramwell \& Sharman, 1999; Hall, 1999; Jamal \& Getz, 1995; Timur \& Getz, 2008; Viren, Vogt, Kline, Rummel, \& Tsao, 2015; Zehrer \& Raich, 2010). Therefore, often - but not always - it is DMOs who employ one or more persons in the role of network manager. These network managers get the task to develop and to serve the network for which they are responsible.

Beaumont and Dredge (2010) argue that network managers need to make a trade-off between different tasks and activities to acquire, on the one hand, a legitimate leadership position within the network while, at the same time, remaining highly inclusive towards stakeholders. Both legitimate leadership, associated with power, and inclusive management strategies, associated with trust, could influence network development positively (Beritelli, 2011; Klijn, Steijn, \& Edelenbos, 2010; Lemmetyinen \& Go, 2009; Provan \& Kenis, 2008). This suggests that it is important for network managers to continuously make the right choices between power-based and trustbased activities and to obtain and display a broad repertoire of, and competence in, a variety of management activities. Deliberately choosing between different activities and approaches thus becomes an important part of the professionalization of network managers (Beaumont \& Dredge, 2010). However, little is known what exactly has to be done under which conditions to accomplish successful network development. A knowledge gap exists with regard to what tourism network managers actually do in their daily practices. As more and more DMOs embrace networks as a promising approach to manage the complicated tourism sector, more knowledge is needed about what kind of activities network managers do in order to reach their goals and how they make the suggested trade-offs between power-based and trustbased management activities (Beritelli et al., 2015; Björk \& Virtanen,
2005; Lemmetyinen \& Go, 2009; Volgger \& Pechlaner, 2015).

This paper puts the spotlight on the network manager. By focusing on the way network managers try to reach their objectives in their daily activities, this paper attempts to provide a better understanding of the persistent paradox between the academic literature, which reports a growing amount of knowledge about the potential benefits networks might have for tourism, and the numerous examples where public institutions or public-private initiatives were unable to organize tourism networks (Del Chiappa \& Presenza, 2013; Lemmetyinen \& Go, 2009; Pavlovich, 2003; van der Zee \& Vanneste, 2015). The goals of this paper are: (a) to reflect on the position, goals and tasks of network managers based on the literature, and (b) to present an empirical picture of the daily work of a number of network managers from a variety of networks within a defined geographical area, being Flanders in Belgium. This knowledge is needed for scientific as well as societal reasons. Scientifically, there is a need to understand more about the balance between power-based versus trust-based activities in relationship to the network's effectivity. Practically, more knowledge is needed that might help DMOs to adapt their management approaches in order to maximize the potential benefits from applying a network approach, as well as for network managers and educational institutions to professionalize the work of network managers in tourism.

\section{Literature review}

\subsection{Networks in tourism}

Since the pivotal work of Coase (1937) and later Porter (1990) fuelled by a manifold of illustrative cases in industrial development such as the industrial organization of the Italian Po Valley or high-tech clusters at Silicon Valley, an approach based on collaboration and nonhierarchical coordination of industrial development has gained importance. Processes like outsourcing and downscaling, as well as an increasing complexity of production chains, value chains, and governance systems, contribute to the demand for an explanatory model taking into account non-contractual and non-hierarchical inter-stakeholder relationships (Porter, 1990). The metaphor of a network was chosen to explain these complex systems of relationships. Originating from mathematics and graph theory, an organizational network is conceptualized as a system in which nodes, being firms, policymakers, and other individuals or groups are connected by ties, such as friendship, agreements, collaborative relationships, and the sharing of information (Wasserman \& Faust, 1994). Networks are often used to describe the interconnected nature of stakeholders in certain geographical regions or around certain topics or themes, such as 'high-tech' or 'innovation' (Powell, Koput, \& Smith-Doerr, 1996) or 'regional food products' (Sage, 2003). Since the field of network studies covers a wide range of disciplines, and the tourism sector is characterized by a set of peculiarities, for example its partial industrialization, high level of fragmentation, and complex interrelated nature (Hartman, 2016; Leiper, 1990; Pearce, 2014), this literature review predominantly uses contributions on tourism networks (e.g. van der Zee \& Vanneste, 2015 for an overview).

Networks provide a way to explain the system of intrastakeholder relationships outside formal contractual structures like firms or organizations, but networks can also be described from a governance perspective (Pearce, 2014; Provan \& Kenis, 2008). Studies into networks often focus on the position of network nodes, centrality, density, the evolution of relationships, and other dynamics within the network, studied in a quantitative way (Del Chiappa \& Presenza, 2013). However, in tourism network studies they seldom take the network as a unit of analysis in order to study governance and network management (Dredge, 2006; Provan \& Kenis, 2008). Local contexts influencing the formation and operation of networks as well as community engagement are often ignored (Pearce, 2014). Del Chiappa and Presenza (2013) highlight how studying networks though a relational perspective takes 
into account how networks contribute to more stakeholder engagement, how trust between network members is developed, which power relations and structures exist, and how reciprocity drives network collaboration. These studies, together with studies into as how networks are, could and should be managed are essential to understand better why the theory about networks in tourism is more positive than practical examples on network formation and development indicate (Del Chiappa \& Presenza, 2013; Lemmetyinen \& Go, 2009; Pavlovich, 2003; van der Zee \& Vanneste, 2015).

Since the network concept was introduced in the tourism literature in the late 1990s it found its way into both academic research on tourism as well as on the policy agendas of destination managers (Beaumont \& Dredge, 2010; Pearce, 2014). This can be witnessed through the emerging of destination management organizations (DMOs) and other tourism organizations rebranding themselves as 'network organizations', public institutions opening-up their decision making, and governance processes to other stakeholders and increasing self-organization of stakeholders in destinations and sectors (Bramwell \& Sharman, 1999; Volgger \& Pechlaner, 2014). A general shift, witnessed in the conversion of destination marketing organizations into management organizations, as well as an increasing attention for tourism management on policy agendas, indicates a re-politicization of tourism (Colomb and Novy, 2016; Volgger \& Pechlaner, 2014). Contemporary destination management moves away from a neoliberal and Fordist system of the public sector creating a context in which the private sector can compete towards a relational system where public and private stakeholders need to collaborate to work towards a competitive and sustainable destination (Del Chiappa \& Presenza, 2013; Porter, 1990). The network approach is thought to be able to act as a relational governance system able to support collaboration and destination management (Del Chiappa \& Presenza, 2013).

\subsection{Managing tourism networks, a relational approach}

The network approach to governance suggests a high level of selforganization and limited hierarchical differences between stakeholders, but several scholars note the necessity of some form of institution and/ or structure that exercises management, leadership, authority and control (Hall, 1999; Nunkoo \& Ramkissoon, 2012; Provan \& Kenis, 2008; Zehrer, Raich, Siller, \& Tschiderer, 2014). Levels of interference of these managing entities in network organization range from virtually none in self-organizing networks with a shared governance structure to a fully brokered network where one governing entity is responsible for network management with limited member-to-member interaction (Provan \& Kenis, 2008). Multiple studies found that creating and managing networks in tourism appears to be troublesome (Beaumont \& Dredge, 2010; Pavlovich, 2003; van der Zee \& Vanneste, 2015, but see Novelli et al., 2006 for a notable exception). Some successful examples exist in relatively small destinations, with a low number of stakeholders and high levels of geographical, cultural and institutional proximity which enable frequent contacts between stakeholders (Pavlovich, 2003; Zach \& Racherla, 2011). However, the complex, multi-scalar and composite nature of tourism reduces the likeliness of spontaneous bottom-up network development (Hall, 1999; Stoffelen \& Vanneste, 2016). An active management of networks is therefore suggested, often with a public stakeholder and/or a publicprivate collaboration, such as a DMO, as the main engine behind the network formation (Beritelli et al., 2015; Lemmetyinen \& Go, 2009; Sheehan, Ritchie, \& Hudson, 2007). The remainder of this paper will focus on how entities, be they DMOs or other types of network management organizations as well as individuals responsible for managing networks work, apply leadership, deal with power and trust and organize the network they are involved in.

Developing, managing and coordinating a network is a complex task. A review of the literature on network management and leadership on tourism management found that managing networks implies simultaneously organizing the network internally through the stimulation of intra-network relationships, as well as positioning the network towards external stakeholders (Provan \& Kenis, 2008; Zehrer et al., 2014). Shifting between these different roles requires individuals or organizations active in network management to master a variety of managerial competencies, matching the various tasks of organizing, managing and brokering networks (Björk \& Virtranen, 2005; Lemmetyinen \& Go, 2009; Presenza \& Cipollina, 2010). Internal network management implies being aware of existing network relations and structures, sentiments and positions of stakeholders towards network goals and objectives, and maintaining communication channels (Beritelli, 2011; Lemmetyinen \& Go, 2009; Petrou, Pantziou, Dimara, \& Skuras, 2007; Zehrer et al., 2014). Positioning the network in relation to external stakeholders implies representing the network or facilitating access to funding opportunities, information or other resources (Beritelli et al., 2015; Beritelli, 2011). In daily practice, network managers are balancing between managing the network internally and strategically positioning between the network and external stakeholders (Gould \& Fernandez, 1989; Lemmetyinen \& Go, 2009; Provan \& Kenis, 2008). This position, both within the network as well as between the network and influential external stakeholders, is important in order to determine the managers power, influence and management options (Beritelli et al., 2015; Nunkoo \& Ramkissoon, 2012; Timur \& Getz, 2008).

\subsection{Governance structure in tourism networks}

Three types of networks can be distinguished based on the structure and the position of the manager (Beaumont \& Dredge, 2010; Provan \& Kenis, 2008). The first type are participant-governed networks (PGN). PGNs are decentralized, bottom-up managed networks linked by informal, horizontal relationships between stakeholders. This network structure facilitates flows of information and the sharing of knowledge and learning, which fosters innovation and product development (Scott, Baggio, \& Cooper, 2008). PGNs are, however, often volatile through the prevalence of weak network connections and the lack of a central, powerful actor coordinating the network (Beaumont \& Dredge, 2010). When active management occurs, this often happens on an ad-hoc basis, and any network member or group of members can act as network managers. These network managers mainly try to increase the proximity between the stakeholders and to facilitate collaborative relationships within the network. By improving the network structure through increasing network ownership and social capital among stakeholders, the network can become more self-sufficient and stronger (d'Angella \& Go, 2009). A second task of network managers in a PGN is representing the network and its members to external stakeholders to improve the network's position. To be able to do this, the network managers need to be aware of the opinions and positions of network members and need to be regarded as a legitimate leader (Beritelli et al., 2015; Gould \& Fernandez, 1989).

The second type are lead organization-governed networks (LOGs), where the network is driven by means of a coordinating role played by a public lead organization. The LOG is positioned in the network and takes the role of coordinating and managing the network, often centralized and organized from the top down (Provan \& Kenis, 2008). These leading organizations focus either on policy formation and implementation, access to resources or the marketing and promotion of a tourist destination or sector (Dredge, 2006). LOG networks are considered as highly centralized with the majority of decisions made by the lead organization. Relationships within the network as well as between the network and external stakeholder are brokered by the lead organization (Provan \& Kenis, 2008). These lead organizations are often gatekeepers through whom network members can gain access to external organizations in order to influence decisions and policymaking and they feed information back into the network (Beritelli et al., 2015; Gould \& Fernandez, 1989). 
A third type of network organization can be found when an intermediary organization external to the network coordinates the network. This network administrative organization (NAO) manages networks as a separate, external administrative body which is neither fully reliant on public support, nor fully originating from network participants. A NAO often works with a board of representatives from the network for its strategic orientation, but operational decisions are made by the NAO itself (Provan \& Kenis, 2008). As in the other types of network organizations, the network manager in a NAO both aims to facilitate stakeholder relationships within the network and connects the network to external parties (Beritelli et al., 2015). The disconnected position of the broker in a NAO compared to a PGN or LOG increases its independence and impartiality but, however, also decreases its proximity to both the network members as well as to external stakeholders. Legitimacy is not self-evident but needs to be earned (Volgger \& Pechlaner, 2014).

\subsection{Operationalizing network management}

The type and intensity of management activities depend on the characteristics of the network (Beaumont \& Dredge, 2010; Provan \& Kenis, 2008). Larger networks, networks with lower levels of trust between members, networks with less obvious consensus on network goals and networks in which members need more competencies for completing network tasks are associated with more interference from the network manager (Provan \& Kenis, 2008). This touches the issue of the internal and external legitimacy of the network manager's position. While high internal legitimacy can reduce the level of interference needed for intra-network management, external legitimacy can improve the opportunities for managers to represent the network or provide access to external resources for network members. Internal legitimacy is highly related with trust between network members and between members and the network as an institution (Beaumont \& Dredge, 2010; Nunkoo \& Ramkissoon, 2012). External legitimacy is associated with power derived from the position of the manager between the network and external stakeholders. While internal legitimacy can also strengthen the position of the network manager towards external stakeholders, e.g. by representing the network or by increasing independence due to financial and organizational support by the network members, tensions exist between gaining internal and external legitimacy, as network managers mostly tend to focus on just one of the two (Provan \& Kenis, 2008).

Network managers can opt for different management approaches depending on the type of network organization and the managers' position and legitimacy in relation to the network (Beaumont \& Dredge, 2010; Beritelli et al., 2015). First, the formation of a clear vision and shared goals is needed to align stakeholders and persuade them to join the network (Beaumont \& Dredge, 2010; Lemmetyinen \& Go, 2009; Presenza \& Cipollina, 2010; Zehrer et al., 2014). The type of goal can be different for different networks, but all networks need a set of shared goals and a common vision to be successful. Second, maintaining transparent and open communication and feedback mechanisms is important for organizing the network (Bregoli \& Del Chiappa, 2013; Lemmetyinen \& Go, 2009; Saxena, 2005; Viren et al., 2015). The goals and visions of a network both need to be communicated to the network members, as well as to external stakeholders, but also feedback mechanisms are important to monitor the position of network members towards the goals and visions. Through communicating with network members, relationships are developed, trust and internal legitimacy increase, and social networks are formed (Viren et al., 2015).

Next to organizing networks, networks need to be managed internally. Pursuing an inclusive and transparent network organization and engagement of members, increases feelings of fairness as well as social capital within the network which and can lead to members taking over the tasks of network managers in the long run (Beaumont \& Dredge, 2010; Beritelli, 2011; Zehrer et al., 2014). Member engagement can be achieved by creating effective incentive systems aimed at rewarding network members for making contributions to the network (Bregoli \& Del Chiappa, 2013). By stimulating stakeholder interaction, collaboration and trust within the network social capital within the network increases. As the level of trust within the network rises, intranetwork ties are strengthened which stimulates collaboration and sharing of knowledge (Beaumont \& Dredge, 2010; Scott et al., 2008; Sørensen, 2007). Internal management activities can increase internal legitimacy through growing levels of trust and social capital originating from strengthened intramember relationships (Zehrer et al., 2014).

Lastly, managers can apply external management through managing relationships with external networks and stakeholders and providing the network with access to resources, information and influence in policymaking (Beaumont \& Dredge, 2010; Dredge, 2006). Power is an important element in the external management of networks (Beritelli \& Laesser, 2011). The position between the network and external stakeholders provides a power-base to network managers if they are, indeed, able to provide access to external resources and funding for network members. A way in which this can be achieved is when network managers are also involved in other networks at the same time, as members or as management staff (Bregoli \& Del Chiappa, 2013). Externally orientated network managers can also give a face to the network. By doing this, the network evolves into an 'entity in its own right, and not simply a group of people or organizations that occasionally get together to discuss common concerns' (Provan \& Kenis, 2008, p243). A network, when it facilitates sharing knowledge between members and has a certain level of consensus among members towards what it exactly means and entails, can evolve into a commonly accepted and demarcated entity, or boundary object, which increases its external legitimacy (Bregoli, Highley, Del Chiappa \& Sodano, 2016). Network members are more likely to give their support towards network managers either when they feel there is something to gain, or when the network appears to be a viable and legitimate organization.

In sum, network managers are confronted with various tasks and activities, which according to the existing literature all seem needed or useful to reach the network's objectives and/or to strengthen their position. In practice managers make a trade-off both between which types of tasks and activities to use, as well as how to apply them based on previous experiences, time and resource constraints (Beaumont \& Dredge, 2010). The question, how network managers make this trade-off remains unanswered.

\section{Methods}

To find out how networks are managed in practice, which management techniques are applied and how network managers make trade offs in choosing which management tasks and activities to apply, a qualitative study was conducted among network managers in Flanders, Belgium. Flanders is the Dutch-speaking, northern region of the federal state of Belgium.

\subsection{Choice of geographical region}

In Belgium, stimulating tourism, leisure and entrepreneurship are tasks of the Flemish and Walloon governments. The regional Flemish administration is responsible for managing the brand of Flanders and stimulating tourism for the entire region. It is also the main engine behind regional tourism policy and determines the focal points on which funding is provided for local initiatives. Provincial administrations and municipalities have a fairly high level of autonomy in deciding how tourism is managed locally, and are in many cases active in managing tourism and stimulating the local tourism sectors (Diekmann, Bryon, \& Cloquet, 2014). Most networks related to tourism are therefore not active on the national level, but either on the regional Flemish, or lower institutional scale levels. The way a network manager interacts with both network members and external stakeholders is influenced by the local institutional context and culture (Dredge, 2006). Therefore, 
we chose to focus the empirical research on the management of networks located in the same region (Flanders), but operating on different institutional scales.

\subsection{Selection of networks}

The empirical part of this study was designed to gain insights in the management activities of network managers by interviewing managers of different kind of networks involved in the stimulation and shaping of local and regional tourism sectors. Including different networks, active in the same institutional context and dealing with the same sector but varying in size, scale, position, and content allows a comparative research design. Comparative research allows to see how and why management approaches differ, and what effects this has on how the networks function (Beaumont $\&$ Dredge, 2010). Through both short explorative interviews with informed keypersons and an online search, 20 tourism networks were selected and the network management organizations of these networks were approached and asked to participate in the study. In total, 15 managers of 12 different network organizations agreed to participate. Tables 1 and 2 give an overview and list the characteristics of the different networks included in this study. Among the networks, some were aimed at stimulating tourism in destinations in which the lead organizations were often DMOs and the members local business organizations, and sometimes interested individuals. In other cases, the networks were sector oriented and aimed at organizing value chains, and bridging touristic supply and demand, or representing and organizing a specific part of the tourism sector, for example touristic attractions or hotels and restaurants. In these cases, the lead organizations often were separate network organizations, based on public private partnerships and the members were mainly businesses.

\subsection{In-depth interviews}

For the in-depth interviews, the main goal was to find out which of the in the literature identified network management tasks and activities (see Table 2 for an overview), were applied by the network managers and how they applied them in their daily management of their networks. The different network managers participated in a qualitative interview, which lasted between one and two hours. The qualitative 'key-person' interview approach was based on the empirical work by Lemmetyinen and Go (2009). This approach starts by asking openended questions to uncover the narrative behind network management, to give a vivid description of daily tasks as well as a more holistic reflection on the hurdles and issues managers encountered while managing networks. By starting from a more abstract and distant position, network managers were not nudged into a specific direction of network management, like stimulating collaboration. In this way, the for the managers most important themes, practices, techniques and issues regarding network management were brought to the table. The interviews consisted of semi-structured, open-ended questions concerning the position of managers towards network management, their daily activities as network managers, their own position within the network, their relationship with external parties and how they broker or stimulate inter and intra-network relationships. All interviews were held in Dutch or English, recorded, transcribed and analysed using NVivo software.

The initial coding scheme listed the management tasks and activities identified in the theoretical framework: Formation of clear vision and goals; maintaining transparent and open communication and feedback mechanisms; Pursuing an inclusive and transparent network organization and engagement of members; stimulating stakeholder interaction, collaboration and trust and External management. The first round of coding gave an insight into which management tasks and activities were applied by the different network managers, After coding the interviews deductively according to this scheme, a second round of coding was done in a more inductive manner by looking for recurring themes within the different initial coding scheme. This second round of coding gave insights into how network managers applied the various tasks and activities, and why they choose to make certain trade-offs in their daily management. The interviews were analysed for recurrent themes by two researchers independently. Differences were resolved by discussion. The identified themes are presented in Table 2, with the initial coding scheme in the table heading and indicated by shading when applied in the different networks and the second round of coding is explained in the table fields, where for the different networks is explained how they apply the different management tasks and activities. The themes matched well with the theoretical framework of this paper, highlighting the work of Provan and Kenis (2008), Beaumont and Dredge (2010) and Beritelli and colleagues (2015). This finding contributes to the validity of the research material. Quotes included in this paper from interviews in Dutch were translated into English by the authors.

\section{Results}

\subsection{Introducing the networks}

The general characteristics of the participating networks are presented in Table 1. As intended, the networks show a wide diversity, in scale level, focus, type, size, governance structure and financing.

\subsubsection{Size and scale}

Networks come in different sizes and shapes. In this study, some networks were relatively small, having not more than 30 members while, at the other end of the spectrum, there are also networks with 300 members or more. With five (out of 12) networks covering the whole of Flanders, the regional (Flemish) scale level is the most prevalent. This is understandable as most political decisions concerning tourism are taken at the regional level and the region is responsible for promoting tourism. Moreover, the Flemish government is also an important funding entity, either direct through ministries, or via intermediary organizations. Networks active at the regional level typically aim at specific sectors or themes, like food production and consumption, heritage or accessible tourism, and often have a wider approach than just tourism. But there are also networks which deliberately embrace tourism and leisure, to give an aim towards a more general thematic focus. This happened for example in network $\mathrm{K}$, which deliberately aimed at making heritage sites accessible for tourists. The regional level was explicitly preferred above the national level by several networks because of language barriers and cultural differences between the Dutch-speaking and the French-speaking parts of Belgium, which would make it more difficult to reach common goals.

Next to the regional level, four networks are active on the provincial level. These networks mainly rely on financial support by the provincial administration. At the provincial level, some networks aim both at a sector as well as a destination. For example, network $\mathrm{F}$ aims at promoting local products which are strongly labeled as originating from that province. Network I is aiming at the promotion of the entire tourism sector in the province, and therefore has a destination focus. On the municipality level two networks are present, both being rather small and having a destination focused approach. Finally, there is one international network consisting of representatives of various European regions such as Tuscany and Catalunya, but located in Brussels. The Flemish secretariat of this network was at the same time responsible for the Flemish interests in this network.

\subsubsection{Governance structure}

Most networks are managed by a Network Administrative Organization (NAO). These independent management organizations are set up to manage the network, either as a formalization of a PGN, or as an independent spin-off of a public initiative to form a network. Eight out of the 12 network managers are active in a NAO, of which four originated from a PGN and were participant-induced, and three were public-induced. One network originally was participant induced, but 


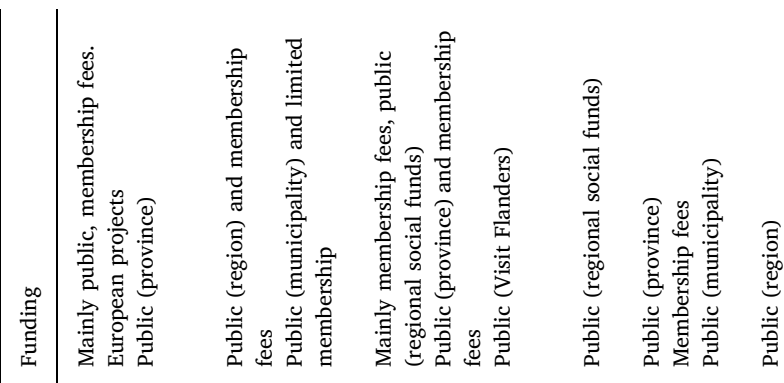

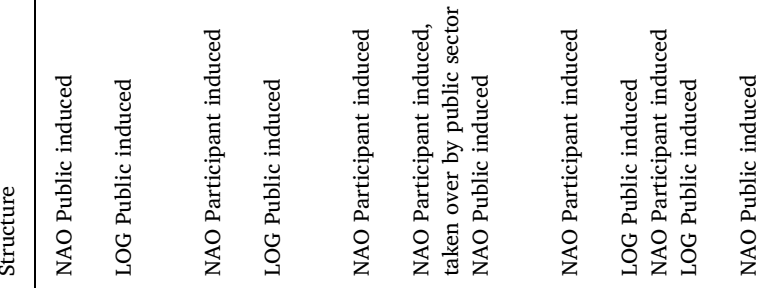

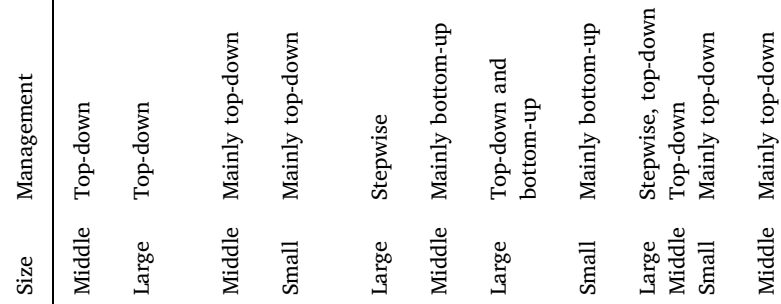

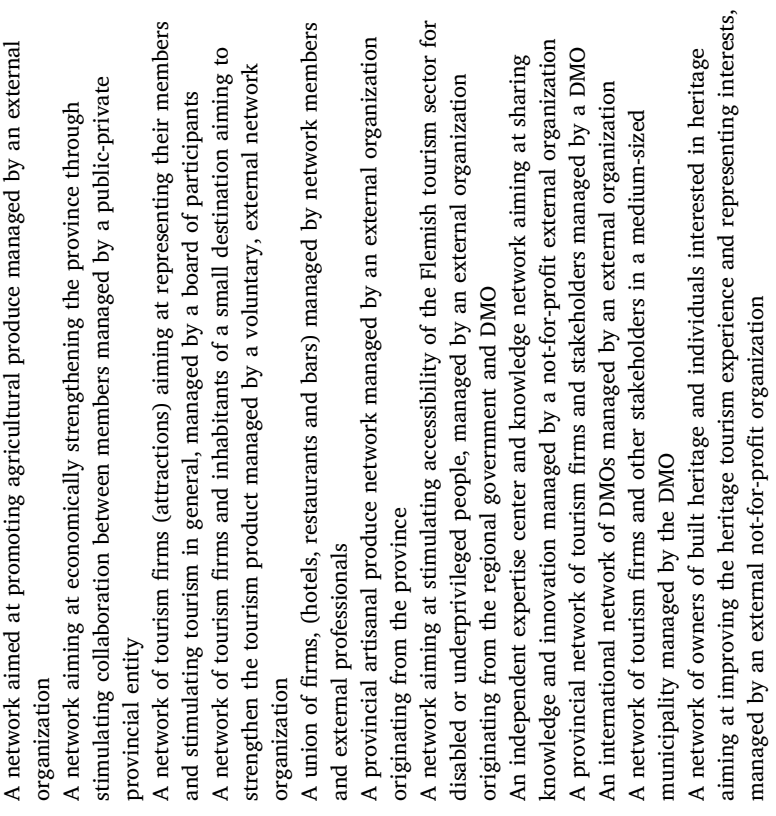

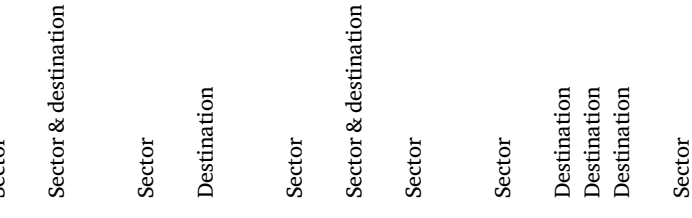

(2)

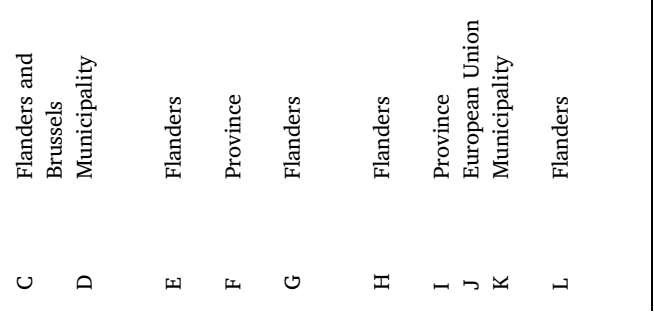


Table 2

Overview of tourism networks (Note: A grey field points out the activity is applied by a network manager, while a white area indicates it is not applied actively.

\begin{tabular}{|c|c|c|c|c|c|}
\hline Network & Clear vision and goals & $\begin{array}{c}\text { Communication and feedback } \\
\text { mechanisms }\end{array}$ & $\begin{array}{c}\text { Transparent and inclusive } \\
\text { organization }\end{array}$ & $\begin{array}{c}\text { Stimulating stakeholder } \\
\text { interaction, collaboration and trust }\end{array}$ & External management \\
\hline A & $\begin{array}{l}\text { Networks sound good in } \\
\text { paper but difficult in } \\
\text { practice: The network vision } \\
\text { holds it all together. }\end{array}$ & $\begin{array}{l}\text { Working towards open } \\
\text { communication. Learn by doing and } \\
\text { see the importance of feedback but } \\
\text { also issues arising from unclear } \\
\text { communication. }\end{array}$ & $\begin{array}{c}\text { Limited inclusion in network } \\
\text { organisation. Small group of supportive } \\
\text { members, but presence of mismatched } \\
\text { expectations. }\end{array}$ & $\begin{array}{l}\text { Fierce competition between network } \\
\text { members and low levels of trust. } \\
\text { Main success is getting academic } \\
\text { partners involved. }\end{array}$ & $\begin{array}{l}\text { Provide limited access to funding. Promote the sector, } \\
\text { but conflicts with members exist over the expectation } \\
\text { to promote individual products. Brokering relationships } \\
\text { between academic institutions and the private sector. }\end{array}$ \\
\hline B & $\begin{array}{l}\text { Clear goals, determined top- } \\
\text { down. } \\
\text { Support the food industry. }\end{array}$ & $\begin{array}{l}\text { Bilateral direct top-down } \\
\text { communication between lead } \\
\text { organization and members. Limited } \\
\text { open and general communication. }\end{array}$ & $\begin{array}{l}\text { Selective collaboration based on } \\
\text { projects, little input from network } \\
\text { members. }\end{array}$ & $\begin{array}{c}\text { Top-down interaction, stimulation of } \\
\text { trust between network management } \\
\text { organization and members, distrust } \\
\text { between members. }\end{array}$ & $\begin{array}{l}\text { Provide access to substantial funding for members } \\
\text { through project-based partnerships to strengthen the } \\
\text { competitiveness of the sector. No representation of } \\
\text { members or promotion of the sector. }\end{array}$ \\
\hline $\mathrm{C}$ & $\begin{array}{l}\text { Vision not exactly known by } \\
\text { network manager, it works } \\
\text { as a guideline. Externally } \\
\text { oriented, promotion of the } \\
\text { sector and members. }\end{array}$ & $\begin{array}{l}\text { Top-down communication via emails, } \\
\text { websites, newsletters aimed at } \\
\text { informing members. }\end{array}$ & $\begin{array}{l}\text { Board consisting of members. Daily } \\
\text { operations by a mix of members and } \\
\text { secretary staff. Threshold to join the } \\
\text { network, but all members are included } \\
\text { and treated equally. }\end{array}$ & $\begin{array}{l}\text { Organizing thematic think tanks and } \\
\text { annual meetings, but not aimed at } \\
\text { stimulation of intra-network } \\
\text { interaction and collaboration. }\end{array}$ & $\begin{array}{l}\text { Match network members with external parties by } \\
\text { organizing workshops and participating in meetings. } \\
\text { Represent the sector at the regional policy level. } \\
\text { Promote the sector and the individual members to } \\
\text { consumers and markets. }\end{array}$ \\
\hline $\mathrm{D}$ & $\begin{array}{l}\text { Promoting the municipality } \\
\text { as a leisure and tourism } \\
\text { destination, mainly aimed at } \\
\text { the local population. }\end{array}$ & $\begin{array}{l}\text { Mainly through informal } \\
\text { communication and personal } \\
\text { relationships with members and } \\
\text { partners. }\end{array}$ & $\begin{array}{l}\text { Constant group of volunteers running } \\
\text { the network in collaboration with the } \\
\text { municipality, not inclusive and limited } \\
\text { transparent. }\end{array}$ & $\begin{array}{l}\text { Organizing informal meetings and } \\
\text { formal events, but not with the goal to } \\
\text { strengthen intra-network interaction } \\
\text { and collaboration. }\end{array}$ & $\begin{array}{c}\text { Organize events, create routes and promote the } \\
\text { destinations and network members, but mainly inward } \\
\text { looking. }\end{array}$ \\
\hline $\mathrm{E}$ & $\begin{array}{l}\text { Vision not exactly known by } \\
\text { network manager. Represent } \\
\text { members, create networking } \\
\text { opportunities and support } \\
\text { and assist members. }\end{array}$ & $\begin{array}{l}\text { Top-down information provision and } \\
\text { bottom-up member consultation } \\
\text { through step-wise feedback } \\
\text { mechanisms and workshops. }\end{array}$ & $\begin{array}{l}\text { The organization is managed by } \\
\text { network members and has a wide } \\
\text { system of member initiatives. } \\
\text { Professional secretarial and } \\
\text { administrative staff. }\end{array}$ & $\begin{array}{l}\text { Actively stimulate members meeting } \\
\text { each other, facilitate inter-member } \\
\text { learning and activate members to take } \\
\text { part in network activities. }\end{array}$ & $\begin{array}{l}\text { Represent the members at local, regional, national and } \\
\text { European policy levels by influencing legislation and } \\
\text { policy. Feed information back into the network. } \\
\text { Organize training and learning opportunities for } \\
\text { members. }\end{array}$ \\
\hline $\mathrm{F}$ & $\begin{array}{l}\text { Bring together stakeholders } \\
\text { working with local produce } \\
\text { and professionalize the } \\
\text { sector. }\end{array}$ & $\begin{array}{l}\text { Informing through email, newsletters } \\
\text { and also direct, personal emails. Use } \\
\text { of social media as well as the website. } \\
\text { Aiming at personal contacts through } \\
\text { face-to-face meetings, but impeded } \\
\text { by growing size of the network. }\end{array}$ & $\begin{array}{l}\text { Board consisting of members. } \\
\text { Membership fee, but promotion in } \\
\text { return, active work to engage members. } \\
\text { Treat members equally, no interference } \\
\text { in disputes between members. }\end{array}$ & $\begin{array}{l}\text { Bring members together through } \\
\text { organizing events and stimulate } \\
\text { collaboration. Events are organized } \\
\text { and hosted by members and aim at } \\
\text { informal networking. }\end{array}$ & $\begin{array}{l}\text { Promote local products to external markets and } \\
\text { represent the sector at the provincial policy level. } \\
\text { Provide a quality label and brand for network members. } \\
\text { Organize events to connect members to consumers and } \\
\text { markets. }\end{array}$ \\
\hline G & $\begin{array}{l}\text { The network vision is used } \\
\text { to strengthen the network: } \\
\text { the right to go on holiday. }\end{array}$ & $\begin{array}{l}\text { Information provision through } \\
\text { newsletters, website and social media. } \\
\text { Feedback moments, information } \\
\text { gatherings and ask actively for input } \\
\text { from members based on leaflets and } \\
\text { publications. Sharing best practices. }\end{array}$ & $\begin{array}{l}\text { Scout for network competencies, } \\
\text { appreciate and acknowledge the role of } \\
\text { the involved members. Clear set of } \\
\text { expectations for joining the network. }\end{array}$ & $\begin{array}{l}\text { Events are organized to stimulated } \\
\text { members that would normally not } \\
\text { meet each other to get in contact in an } \\
\text { informal environment. Aiming at } \\
\text { finding common interfaces, brokering } \\
\text { intra-network relationships. }\end{array}$ & $\begin{array}{l}\text { Coordinate offer and demand by brokering } \\
\text { relationships between network members and markets as } \\
\text { well as between the private sector and institutions. } \\
\text { Represent a weak consumer group and promote } \\
\text { corporate social responsibility. }\end{array}$ \\
\hline $\mathrm{H}$ & $\begin{array}{l}\text { Stimulate sustainable } \\
\text { employment in the } \\
\text { Hotel/Restaurant sector. }\end{array}$ & $\begin{array}{l}\text { Information provision through news } \\
\text { flashes and newsletters to partners. }\end{array}$ & $\begin{array}{l}\text { Board consisting of other important } \\
\text { networks and social partners, not open } \\
\text { for new partners. }\end{array}$ & $\begin{array}{l}\text { Issues organizing meetings due to } \\
\text { busy agendas of members. }\end{array}$ & $\begin{array}{l}\text { Provide knowledge through research and give policy } \\
\text { recommendations, but no active representation. }\end{array}$ \\
\hline I & $\begin{array}{l}\text { Be an expertise center, } \\
\text { promote tourism } \\
\text { destinations, create products } \\
\text { (routes). Service provision } \\
\text { to members and tourists. } \\
\text { 'Being the best DMO } \\
\text { around'. }\end{array}$ & $\begin{array}{c}\text { Information provision through } \\
\text { newsletters, annual reports and } \\
\text { limited via internet and social media. } \\
\text { Frequent meetings at regional levels, } \\
\text { biannual meetings for all } \\
\text { stakeholders. Direct step-wise } \\
\text { communication with members } \\
\text { through regional managers. }\end{array}$ & $\begin{array}{l}\text { No membership fees, but also no } \\
\text { inclusion of members in network } \\
\text { organization or influence on projects } \\
\text { (e.g. routes). No interference in } \\
\text { competition between members. }\end{array}$ & $\begin{array}{c}\text { Regional and biannual meetings, but } \\
\text { not focused on stimulating member } \\
\text { interaction. Active } \\
\text { stimulation of networking between } \\
\text { elite members (mayors of } \\
\text { municipalities). }\end{array}$ & $\begin{array}{l}\text { Provide information on the tourist sector for members } \\
\text { by conducting research. Provide a quality label for } \\
\text { tourism businesses. Issues related to changing the } \\
\text { political landscape in which municipalities are } \\
\text { stepping back. Conflicts with other networks and } \\
\text { administrations, but collaborating with others. }\end{array}$ \\
\hline $\mathrm{J}$ & $\begin{array}{l}\text { Representing members at } \\
\text { European Commission. } \\
\text { Collaborating with private } \\
\text { sector and academic } \\
\text { institutions for sustainable } \\
\text { and competitive tourism. }\end{array}$ & $\begin{array}{c}\text { Information to all members through } \\
\text { newsletter, website, yearly general } \\
\text { assembly and other. Personal } \\
\text { bilateral communication on task } \\
\text { forces or specific projects, permanent } \\
\text { secretary available for feedback from } \\
\text { members. }\end{array}$ & $\begin{array}{l}\text { Balancing general inclusiveness and } \\
\text { pragmatic bilateral collaboration. Task } \\
\text { forces in which members are selected to } \\
\text { get European funding for specific } \\
\text { projects. Inclusion depends on personal } \\
\text { relationship and attitude of the member. }\end{array}$ & $\begin{array}{l}\text { Stimulating project-based alliances } \\
\text { between (public) network members, } \\
\text { external private sector and academic } \\
\text { institutions. No active stimulation of } \\
\text { member interaction. } \\
\text { Challenge for better using the present } \\
\text { tacit knowledge members have. }\end{array}$ & $\begin{array}{l}\text { Active at European Commission for information and } \\
\text { funding opportunities and representing the destinations } \\
\text { at the European Commission. Broker information flows } \\
\text { which provides strategic value for members. }\end{array}$ \\
\hline K & $\begin{array}{l}\text { Promote tourism, create } \\
\text { products (routes), stimulate } \\
\text { overnight tourism and } \\
\text { promote collaboration } \\
\text { within the industry. }\end{array}$ & $\begin{array}{l}\text { Top down formal communication to } \\
\text { informing members. Struggling with } \\
\text { how to handle feedback. Aimed at } \\
\text { yearly event to inform members, but } \\
\text { recently abandoned. }\end{array}$ & $\begin{array}{l}\text { Selection of members made by DMO, } \\
\text { communicated top-down. Not open for } \\
\text { inclusive role of members for network } \\
\text { organization. }\end{array}$ & $\begin{array}{l}\text { Organize sector meetings, but } \\
\text { difficult to get members to join due to } \\
\text { busy agendas and timing. }\end{array}$ & $\begin{array}{l}\text { Promotion and creation of tourism routes, and } \\
\text { promoting members along these routes to customers. }\end{array}$ \\
\hline $\mathrm{L}$ & $\begin{array}{l}\text { The network vision is the } \\
\text { starting point of any } \\
\text { network. Opening heritage } \\
\text { for visitors. }\end{array}$ & $\begin{array}{l}\text { A phase of exploration, sending } \\
\text { newsletters, visiting candidate } \\
\text { members and organizing events to } \\
\text { find new members. Communication } \\
\text { with existing members is top-down } \\
\text { and based on information provision. }\end{array}$ & $\begin{array}{l}\text { Network membership is allowed in } \\
\text { return for active participation, no } \\
\text { membership fees. Inclusion on specific } \\
\text { projects, but not on network } \\
\text { organization. }\end{array}$ & $\begin{array}{l}\text { Organizing events and conferences on } \\
\text { a yearly basis to share knowledge and } \\
\text { attract new members, but not for the } \\
\text { purpose of stimulating intra-network } \\
\text { collaboration. }\end{array}$ & $\begin{array}{l}\text { Connect the general public to heritage locations, by } \\
\text { promoting heritage locations and offer benefits and } \\
\text { discounts to members visiting these locations. } \\
\text { Connecting heritage sites with expertise centers and } \\
\text { provide learning through collecting best practices and } \\
\text { maintaining relationships with international networks. }\end{array}$ \\
\hline
\end{tabular}


the network is now incorporated by a NAO that is heavily funded by and linked to the provincial administration. All NAO networks are characterized by having an active board of network members determining the aims and directions of the network, while most also have active working groups or 'task forces' of network members working on specific themes. In many cases, the NAOs act as a secretariat dealing with daily contacts with network members and the administration and organization of network activities, but most also act as the network's 'face', both internally and as the network's representation towards external parties. While participants are - to various degrees - important in NAO managed networks, fully PGNs are not identified during this research in the Flemish tourism sector. This does not mean there are no participant governed networks present, but due to their often informal organization structure they are difficult to identify. The other governance structure encountered is the LOG network, in which a public party, often a public DMO, acts as a network manager. Four examples of LOGs were identified in this study. They are characterized by a top-down management approach, and are not reliant on private stakeholders for funding. In general, these LOGs are active in a certain area, a province or municipality, focusing at either stimulating tourism in the destination or stimulating economic growth in the sector in more general terms by creating a network of public, private and academic members working together on specific projects.

\subsection{Formation of clear vision and goals}

All interviewed network managers stressed the importance of defining a shared vision and a clear common goal for the network (Table 2). However, while concrete network goals and a shared vision were widely acknowledged as fundamental for network development, there was no consensus of what a network approach actually entailed, nor about what a network actually is and could do to reach its goals. Four network managers indicated they used the term network mainly because it is currently a 'fashionable word' for explaining business as usual (network D, H, K\& L).

In the past, it was all about relationships and getting to know people. Now, one calls it 'networking' (Network D, Municipal LOG).

The managers of network $\mathrm{C}$ and $\mathrm{E}$ admitted there was a rather generic network goal which acted more like a label. The goals and vision of the different networks were created and/or shaped in consultation with network members.

Yes, well, we don't have a communist point of views that we have to enforce it, our vision. I actually need to think what it actually is. It's about guarding our member interests and create added value in a professional and fair way for the sector, more or less (Network E, Flemish NAO)

\subsection{Maintaining transparent and open communication and feedback mechanisms}

Communication is vital for informing, getting to know the members, find out what happens at the grassroots, shaping and reshaping network goals and vision, and winning trust from the members. Communication is approached differently by different managers. Some primarily communicate top-down and unidirectional, mainly by providing information, while others strive for an open and ongoing dialogue and actively try to elicit members' ideas and opinions. Almost half of the networks managers described networking mainly as informing network members (network B, C, H, K \& L) by providing information through newsletters, news flashes, websites, social media or meetings.

Traditionally, we have two main communication channels, being of course our website and our information brochure which we publish once a year (Network K, municipal LOG)
The other network managers (networks A, D, E, F, I, J \& L) had a more open and transparent approach to information provision as well as a high esteem of personal communication and feedback mechanisms. While these network managers stressed the importance of informal communication channels and feedback from members, network $\mathrm{K}$ mainly saw this as a nuisance frustrating product implementation. Even though the importance of open bidirectional communication was often stressed, it appeared difficult to implement for some network managers.

We should have communicated better with the companies who wanted to be involved from the start. When they showed interest in the network, then we ought to keep their interest and serve them to their needs almost. Because if... waiting too long only once can be enough to lose interest and it won't be possible to get it back and gain their trust again (Network A, provincial NAO)

Organizations that recently adopted a network approach, or network managers relatively new to the job, were more likely to restrict themselves to information provision, while more experienced network managers valued both transparent information provision as well as bidirectional communication and feedback. In multiple more mature networks, communication was found to be subject to a learning process (networks E \& F). Top-down, unidirectional communication was more often present in networks with a LOG structure, whereas managers in a participant induced NAO structure tend to create feedback mechanisms and are open to input by network members. Managers indicate that it is necessary to invest in the network by keeping an ongoing dialogue with the network members but many find this difficult to effectuate.

\subsection{Pursuing an inclusive and transparent network organization and engagement of members}

Network A, C, E, F, H and L have boards consisting of members, which assures a certain level of democratic decision making within the network. While some networks actively work to select new board members (networks C, E \& F), other boards were fairly stable and not necessarily open to new members joining in (networks A, H\&L). Especially participant induced NAO-managed networks were likely to have a board of members, while LOG-managed networks, as well as some public induced NAO-managed networks did not have any member involvement in formal decision making. Network B, for example, applied a strong top-down management approach, actively placing themselves in a hierarchic position in relation to network members.

When we entered the domain there was nobody... there were a lot of players, but no team. Then we came in, and said: 'We're going to create a network structure in here'. (Network B, provincial LOG)

A number of networks tend to focus strongly on member engagement for both network management as well as specific network activities (network C, E, F, G\&J). These network managers organize, for example, working groups consisting of network members or engage network members in organizing events. Several networks stressed open communication towards all members on participation opportunities was important, but actual member engagement was reached through personal communication.

People need to be able to do it, need to want to do it and thirdly we see very often people need to be asked to participate. If we ask, so to speak, would you be interested in joining? Then the chance someone would participate in the network increases enormously, compared to just sending a letter to all members asking who would like to actively participate in network activities (Network E, Flemish NAO)

In general, network members combine open, transparent information provision to all members with selective, personal communication to separate members on specific themes and topics, although several network managers found it difficult to handle this double approach properly for fear of being seen as unfair which would impede their internal legitimacy. 
It's not evident to win trust from each network member always. That takes time. And a lot of energy. I notice there is a lot of distrust between different members [...] You can't always collaborate with everybody, you choose the member that matches best with the current project, but there is always another member who feels disadvantaged. But well.. I continuously need to answer for my choice. That is not easy at all. (Network B, provincial LOG)

According to the managers who acknowledge the importance of engaging members (Table 2), this improves trust in the total network. Managers could encourage the formation of trust by transparency and open communication. However, the downside of open communication is the risk of people trying to freeride or steal ideas, which may have a detrimental effect on trust and further network development. In network I, a conflict arose because an event switched locations induced by one member affecting another, while in network $\mathrm{F}$ one member plagiarized the idea of a new brand of beer from another. In both cases, the network manager chose not to interfere. Network B responded to issues like this by being less open in its communication.

We experienced this in the past. Some of our members came up with ideas, and eventually others hijacked the ideas and used them for themselves. This is something we try to avoid now, and this is of course the issue with open communication. (Network B, provincial LOG).

\subsection{Stimulating stakeholder interaction, collaboration and trust}

Increasing trust between network members, by stimulating interaction and collaboration, increases social capital and allows network structures to thicken, according to the managers of network E, F and G. This process, however, can only succeed when a certain level of network transparency and opportunities for feedback are present, which in practice was only found to be stimulated in half of the networks (Table 2). Communicating with members, being open to feedback and having empathy for the perceptions of network members were considered essential for successful stakeholder management according manager E and F. In these networks, a common ground and trust between network members was seen as an important foundation on which strong personal relationships were built, to which network manager G add the importance of a level playing field without hierarchies.

The psychological aspect, right? And stakeholder management. These are heavily underestimated. Because it's crucial, we are a partner in between partners and we do not place ourselves in a hierarchical position. (Network G, Flemish NAO)

When collaboration is stimulated, members are more likely to meet each other face-to-face and interact. This interaction can lead to collaboration which lead to the sharing of tacit knowledge and joint production of new and innovative products, as acknowledged by manager $\mathrm{F}$. To fuel interaction and collaboration, manager $\mathrm{F}$ states it is important to create an environment which is familiar and in which network members feel at ease. The environment ranges from digital platforms to regular meetings where network members can interact:

[We need to] make sure that everything you do [as a network manager] is in line with the environment the members live in. To ensure that they can see common ground. (Network F, provincial NAO).

Networks E, F and G are examples of networks in which the managers actively increased collaboration between network members by organizing meetings on a regular basis. During these meetings network members can meet each other, collaboration between members was facilitated, and cross fertilization of ideas and innovative product development occurred. Network manager F indicated that organizing these meetings was a process of learning by doing, and it took some time and effort to find out what types of meetings were valued by the network members. He had noticed that during informal, low threshold events, entrepreneurial stakeholders started to mingle and exchange ideas or products and found each other without further interference by the network manager. Stimulating stakeholder interaction was seldom achieved through the application of ICT's or digital platforms. In some cases, the network did host an member-only accessible intranet (Network C \& E), but it was mainly used to share documents and information instead of stimulating stakeholders to interact digitally.

\subsection{External management}

The last main task of network managers was found to be actively positioning themselves between the network and external stakeholders. The majority of network managers who were active in positioning themselves between the network and external stakeholders assisted their members in connecting to markets and/or consumers (network C, D, E, F, G, I \& L). Less often, managers used this positioning to represent the network to external stakeholders, such as policymakers (network $\mathrm{E} \& \mathrm{~J})$.

Our main task is to defend the interests of our members, whom we represent from the local level to the European level (Broker E, Flemish PGN).

Another way managers tried to position themselves between the network and external stakeholders was to facilitate access to funding opportunities (network B, I\&J). These network managers organized access to public funding on the provincial, regional, or European level, which was possible through both their connections with funding organizations, as well as their knowledge on how to obtain funding. Often, these network managers choose bilateral partners or small groups of members with whom to apply for funding on specific projects (network B \& I), but network $\mathrm{J}$ actively provided members with information on how to acquire funding.

Now, with this situation of crisis, our members are looking more and more for economic support. So, this is why it is important to have this influence on European tourism policies. [...] it is also important to let our members know what Europe is looking for in order to streamline their strategy more in accordance to what 'Europe' could finance (Network J, European NAO).

The position of the manager in between the network and external parties can, however, also have an adverse effect. All networks in this study, except network E, were found to be directly, or indirectly, dependent on the Flemish or local government for financial support. With the threat of public budget cuts and the endangered existence of the provincial administration level, the majority of the managers were insecure about the continuation of their networks. One of the brokers showed his concerns:

The future is compromised by the threatened survival of the province. This is what we are most concerned about. There is an influential political party in Flanders, which wants to abolish the provinces. Our resources come from the province, so if that happens, we are forced to cease the network (Broker I, provincial LOG).

Another concern was that this position remains volatile because when the contacts with external stakeholders or access to external funding disappear, their position towards the network changes as well

Sometimes, one of your contacts in an organization leaves. Then, he or she will be replaced and depending on the willingness of the new person, you can or can't get access to certain information. (Network L, Flemish NAO)

In practice, network managers found themselves often vulnerable due to financial dependence on external public sector parties. The NAO networks $\mathrm{C}$ and $\mathrm{E}$ are mostly reliant on membership fees and the NAO 
networks F and G were less insecure about their future, as they acknowledged that if financial support ceased, the members would be willing to take over a bigger part of the network management. The position of these networks is strengthened by the support of the network members, financially, organizationally but also morally. Knowing the network members support the network increases the confidence and power of network brokers, which makes it possible for brokers to represent the network better and have more influence on policymaking.

\section{Discussion: The strategic position of the network manager}

The tourism sector is notoriously difficult to manage because it consists of a manifold of unrelated entities only partially dependent on tourism lacking a hierarchical chain of command (Leiper, 1990; Pearce, 2014). In these situations, gaining competitive advantage should be sought through the formation of networks consisting of less-formalized relationships which are based on trust, reciprocity and inclusive governance (Bornhorst et al., 2010; Dredge, 2006; Saxena, 2005; van der Zee \& Vanneste, 2015; Volgger \& Pechlaner, 2014). Although some authors claim that power and authority may even have adverse effects on network relationships (Keast et al., 2004), the overall picture from the literature shows that both legitimate leadership, associated with power, and inclusive management strategies, associated with trust, could influence network development positively in the tourism sector (Beritelli, 2011; Klijn, Steijn, \& Edelenbos, 2010; Lemmetyinen \& Go, 2009; Nunkoo \& Ramkissoon, 2012; Provan \& Kenis, 2008;). This means that it is important for network managers to obtain a broad repertoire of and competence in a variety of management activities and to make continuously a tradeoff between power-based and trust-based management activities. Unfortunately, the literature also shows that in daily practice, failed examples of tourism networks outnumber the successful ones (Del Chiappa \& Presenza, 2013; Lemmetyinen \& Go, 2009; Pavlovich, 2003; van der Zee \& Vanneste, 2015).

In order to get a better understanding about the reasons for this gap between theory and practice, and also to find directions how this gap could be bridged, a series of interviews was held with network managers of 12 networks varying in size, scale, and structure. The main conclusion from these interviews is that all network managers in the study proved to be very active with regard to power-based activities, such as top-down information provision, organization of events and lobbying, but the majority spent less or no time on trust-based activities, such as bidirectional communication with the network members, seeking ideas and opinions, promoting member engagement and facilitating inter-member exchanges. Thus, the first conclusion of this paper is that a main reason why so few examples of successful tourism networks are found, is simply, because most network managers hardly invest in trust-based activities, which, according to the literature are dearly needed to develop and maintain active networks in the tourism sector (Bornhorst et al., 2010; Nunkoo \& Ramkissoon, 2012; Pavlovich, 2003; Provan \& Kenis, 2008; van der Zee \& Vanneste, 2015; Volgger \& Pechlaner, 2014; Zehrer et al., 2014).

The interviews also give some indication why the interviewees, who all consider themselves as network managers and talk amply about how they manage their network, yet display so few activities which in the literature are seen as core activities for successful network management:

Insufficient commitment to the network concept. Several network managers indicated that they primarily used the term 'network' because it was fashionable to do so. The interviews showed that these persons had not adapted their activities, but continued to do what they used to do before the term 'network' became fashionable. Only those network managers who articulated clear goals relating to 'the network as a community' also reported activities such as stimulating and facilitating inter-member collaboration. They also stressed - much more than the others - the importance of personal, bidirectional communication apart from the usual top-down information channels, such as a network website and regular newsletters. This finding confirms the conclusion from the literature, that it is important for networks to develop a common goal and shared vision network (Beaumont \& Dredge, 2010; Bregoli et al., 2016; Lemmetyinen \& Go, 2009; Presenza \& Cipollina,2010). This paper adds that network goals and visions should be more than just a piece of paper, but should be shaped and reshaped through bidirectional communication with members and those who are responsible for the network should live up to it, in order to make the network work. The chosen goals and orientation of the network, influences how a network should be managed (Pearce, 2014).

Insufficient priority to get the network working. Several network managers claimed that network members were very busy people who did not have the time to participate in network activities or events; this made them reluctant to organize meetings for fear that nobody would turn up. However, those networks that organized informal meetings in which their members could develop personal relationships were thriving and reported being able to engage network members more. One of these network managers even mentioned the organization of informal, low-threshold meetings as the golden tip for successful network development. Time is often synonymous with priority. If people mention a lack of time, they often mean the activity has a low priority. So, it is important for network managers to have an open eye for potential membership benefits. As Provan and Kenis (2008) mentioned, it is important that members experience benefits from the network in order to attach them to the network, which is highly related to a certain stability of the network. Stability is seen as critical for maintaining internal and external legitimacy. Stability helps to form relations between network members while instability is detrimental for network outcomes as it impedes the likeliness of members to invest time and resources in the network Bregoli et al. (2016)). Apart from material benefits, such as project funding or access to relevant information, it helps when being a member has immaterial benefits as well. A high willingness for being a part of the network is often mentioned as an important driver in networks where the manager adopts an inclusive, transparent, bidirectional and personal communication style.

Intrinsic tensions within the job. Network managers do not have an easy job because they continuously have to cope with seemingly contradictory demands. When a network manager wants to be fair and inclusive to all members, for instance, the best way is to provide the same information at the same time to all members and invite everybody to participate. This approach, however, is at odds with the personal approach which, according to the literature (Beaumont \& Dredge, 2010; Lemmetyinen \& Go, 2009; Saxena, 2005; Viren et al., 2015), is needed for increasing social capital and mutual trust, which in its turn is necessary to really engage members in the network's activities. But, then, other people may claim to have been left out, which reduces trust in the fairness and openness of the network. All network managers who favored a trust-based approach mentioned these problems and dilemmas, giving vivid examples from daily practice. Another example is that sharing ideas might involve risks that ideas are stolen or activities taken over. Network managers found it difficult to deal with these issues. This asks for further professionalization, targeted training and education.

Network managers were found to spend a lot of time on formal communication with the members on the one hand, and positioning and legitimizing the network towards external stakeholders, including funding organizations, on the other. This might work if the efforts to get funding or enhance the network's visibility are successful (Bregoli et al., 2016). But if less successful, this strategy is likely to work as a doubleedged sword and will threaten the network manager's legitimacy both internally and externally (Pearce, 214; Timur \& Getz, 2008; Volgger \& Pechlaner, 2015). The empirical results show this not just a 
theoretical risk. Most of the interviewed managers reported spontaneously about the insecure political situation in Belgium, which, combined with looming budget cuts in the public domain, was considered a real danger for their network's continuity. The high dependency on public funding, and current insecurity proved to make strategic positioning a complicated task and reduced internal legitimacy of network managers. Dealing with a heavy reliance on external funding and the influence of political volatility was an issue not covered in the initial literature review on managing tourism networks, but was found to be an important factor influencing both managing activities and network performance. While, in theory, a networked approach to tourism governance could increase the capacity of the tourism sector to adapt to this changing context and become more resilient (Zehrer \& Raich, 2010), the findings in this paper indicate that also the opposite might happen. The limited formal power and dependency on external parties impedes the position of network managers and can cause entire networks to disintegrate. The solution might be found in enhancing the network manager's informal power.

Fig. 1 translates the literature-identified network management tasks and activities and the interdependent relationship between top-down power-based management and more bottom-up trust-based management uncovered in the empirical part of the study into a conceptual model. Internal and external legitimacy are interrelated and can strengthen each other (Beritelli, 2011; Klijn et al., 2010; Lemmetyinen \& Go, 2009; Nunkoo \& Ramkissoon, 2012; Pearce, 2014; Provan \& Kenis, 2008). The power of network managers is both dependent on the ability of network managers to broker connections to external stakeholders, for example to get access to funding, but also on the internal legitimacy the members ascribe to the network managers (Pearce, 2014). The internal legitimacy is determined by the added value members see in the network and their willingness to contribute to the network (Bregoli et al., 2016). The added value of the presented approach is the interrelationship between internal and external management applied by network managers, and the role trust and power play in these approaches. This results in the conclusion that when formal coercive ties are lacking, power and legitimacy of leadership can be gained through strengthening intra-network relations and trust

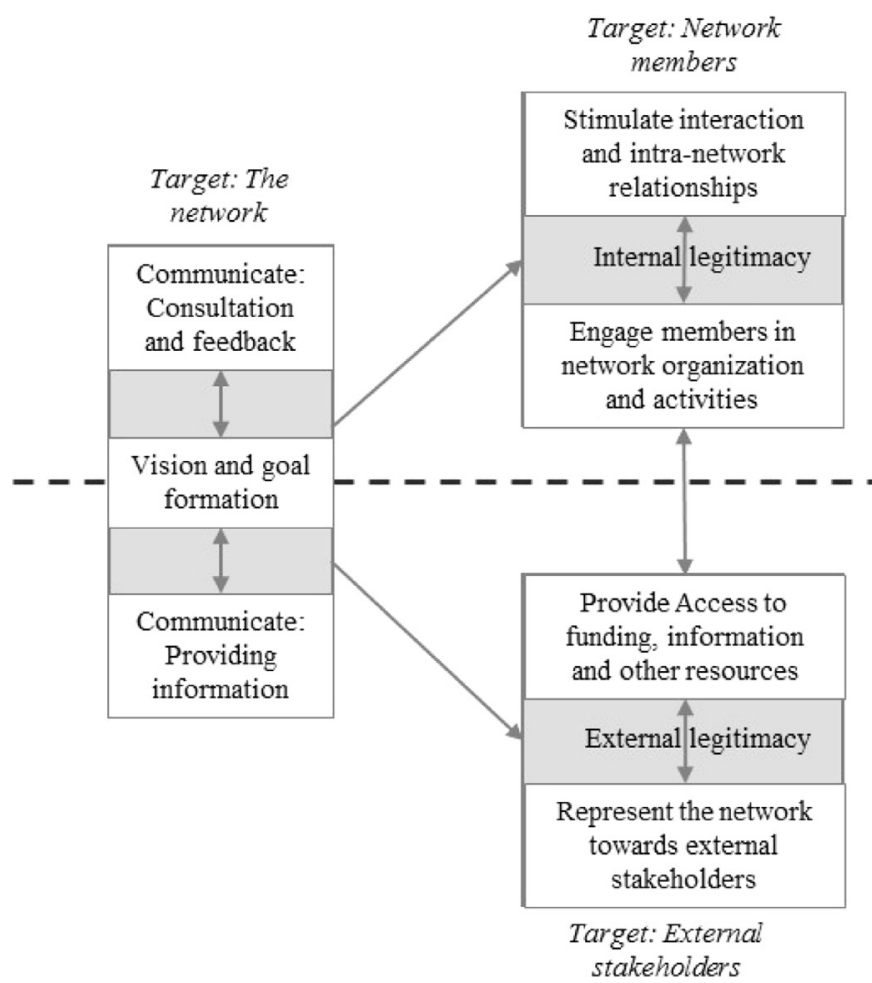

between members. However, most network managers in this study showed to be not aware of this potential powerful mechanism. This model suggests managers should make the trade-off between different approaches to network management more thoughtfully. Managers should switch between positions such as brokering external and internal network relationships instead of maintaining a fixed position (Beaumont \& Dredge, 2010; Beritelli et al., 2015). The present study, however, shows the position of most network managers in practice to be more static, mainly focusing on organizing the network and the network's position in relation to external stakeholders.

\section{Recommendations and limitations of the study}

Although the design of this study does not permit conclusions about the effectiveness of the networks, the optimistic tone of voice about future prospects of those networks that embraced bidirectional communication with their members and fostered members' ideas and initiatives were in sharp contrast with the pessimistic or worrisome stories of networks which restricted themselves to a top-down communication approach, in particular when they were also heavily dependent on public funding. This paper therefore recommends that organizations that wish to apply a networked governance perspective in a sector or destination, should include active networking by skillful network managers, applying trust-based management approaches and bidirectional communication. Intranetwork trust increases the strength of the network, and in extent the legitimacy of the position of the network manager. Bidirectional communication and stakeholder engagement ensures commitment to the network goals.

A network manager should function as a broker by positioning him, her or themselves between internal expectations and external pressure. This means shifting positions between stimulating intra-network interactions to allow mutual trust and social capital to grow and representing the network towards external stakeholders. Network managers need to be able to take both positions, as they need to be aware of intra-network dynamics and structures in order to be a legitimate leader. Network managers were found to learn by doing, which is a necessity since at this moment there are limited training opportunities

Fig. 1. A schematic representation of network management.
Trust-based network management

Power-based network management 
for network managers in tourism available in higher tourism education. As this study indicated, network managers were in general more focused on external management, in combination with a relatively weak knowledge of what the network concept exactly entails, our main policy recommendation is to create professional training schemes in which tourism professionals, destination managers, or network managers are informed on the importance of internal, trust-based management activities such as engaging stakeholders and stimulating network member interaction.

The strength of this study is that the chosen research design provides an in-depth insight in how network managers balance management approaches and decisions within the given context. This approach, however, also comes with inherent limitations, which are at the same time sources of inspiration for further research to test the validity and improve the generalizability of this study's findings. Three potentially interesting research routes were identified. First, since this study looked into the daily practices of network managers from the perspective of the managers themselves, future research should also include the perspective of network members on the relative effectiveness of different management approaches. Triangulating the results by including network members in the research might provide additional insights into the impact of the applied management approaches, varying in the level of mutual trust and social capital, on network development. Second, the findings presented here suggest that peculiarities caused by the specific political system in Belgium, such as the strong interference of public institutions in tourism management and the expected changes within the institutional landscape, affect the results of this study. Repeating the study in different institutional contexts could provide valuable new insights. Thirdly, the qualitative nature of this study provided explorative results into the tasks and trade-offs of network managers. Either delving more deeply into network management, through for example ethnographic research, or testing the position of network managers towards the different identified management tasks and activities in a quantitative way could provide valuable new information on the practice of network management. As tourism management is finding its way into policy agendas in an era of governance and networking, more research is needed into how tourism can be managed according to a network perspective.

\section{Acknowledgements}

We would like to thank Arie Stoffelen, Arja Lemmetyinen and the anonymous reviewers for their constructive feedback and comments. Our special thanks goes to Prof. Frank Go, who unfortunately recently passed away. Frank Go provided the intellectual foundation of this paper and the ideas on which it is build. This paper is part of the doctoral thesis of Egbert van der Zee which is funded by a grant from the Institute for the Promotion of Innovation through Science and Technology in Flanders (IWT) (Grant number: 121699).

\section{References}

Baggio, R., Scott, N., \& Cooper, C. (2010). Network science: A review focused on tourism. Annals of Tourism Research, 37(3), 802-827. http://dx.doi.org/10.1016/j.annals. 2010.02.008.

Beaumont, N., \& Dredge, D. (2010). Local tourism governance: A comparison of three network approaches. Journal of Sustainable Tourism, 18(1), 7-28. http://dx.doi.org/ 10.1080/09669580903215139.

Beritelli, P. (2011). Cooperation among prominent actors in a tourist destination. Annals of Tourism Research, 38(2), 607-629. http://dx.doi.org/10.1016/j.annals.2010.11. 015 .

Beritelli, P., Buffa, F., \& Martini, U. (2015). The coordinating DMO or coordinators in the DMO? An alternative perspective with the help of network analysis. Tourism Review, 70(1), 24-42. http://dx.doi.org/10.1108/TR-04-2014-0018.

Beritelli, P., \& Laesser, C. (2011). Power dimensions and influence reputation in tourist destinations: Empirical evidence from a network of actors and stakeholders. Tourism Management, 32(6), 1299-1309. http://dx.doi.org/10.1016/j.tourman.2010.12.010.

Björk, P., \& Virtanen, H. (2005). What tourism project managers need to know about cooperation facilitators. Scandinavian Journal of Hospitality and Tourism, 5(3), 212-230. http://dx.doi.org/10.1080/15022250510014354.
Bornhorst, T., Ritchie, R. J. B., \& Sheehan, L. (2010). Determinants of tourism success for DMOs \& destinations: An empirical examination of stakeholders' perspectives. Tourism Management, 31(5), 572-589. http://dx.doi.org/10.1016/j.tourman.2009. 06.008.

Bramwell, B., \& Sharman, A. (1999). Collaboration in local tourism policymaking. Annals of Tourism Research, 26(2), 392-415. http://dx.doi.org/10.1016/S0160-7383(98) 00105-4.

Bregoli, I., \& Del Chiappa, G. (2013). Coordinating relationships among destination stakeholders: Evidence from Edinburgh (UK). Tourism Analysis, 18(2), 145-155. http:// dx.doi.org/10.3727/108354213X13645733247657.

Bregoli, I., Hingley, M., Del Chiappa, G., \& Sodano, V. (2016). Challenges in Italian wine routes: Managing stakeholder networks. Qualitative Market Research: An International Journal, 19(2), 204-224. http://dx.doi.org/10.1108/QMR-02-2016-0008.

Brouder, P., \& Eriksson, R. H. (2013). Tourism evolution: On the synergies of tourism studies and evolutionary economic geography. Annals of Tourism Research, 43, 370-389. http://dx.doi.org/10.1016/j.annals.2013.07.001.

Coase, R. H. (1937). The nature of the firm. Economica, 4(16), 386-405. http://dx.doi. org/10.1111/j.1468-0335.1937.tb00002.x.

Colomb, C., \& Novy, J. (Eds.), (2016). Protest and resistance in the tourist city.. London: Routledge.

d'Angella, F., \& Go, F. M. (2009). Tale of two cities' collaborative tourism marketing: Towards a theory of destination stakeholder assessment. Tourism Management, 30(3), 429-440. http://dx.doi.org/10.1016/j.tourman.2008.07.012.

Del Chiappa, G., \& Presenza, A. (2013). The use of network analysis to assess relationships among stakeholders within a tourism destination: An empirical investigation on Costa Smeralda-Gallura, Italy. Tourism Analysis, 18(1), 1-13. http://dx.doi.org/10.3727/ $108354213 X 13613720283520$.

Diekmann, A., Bryon, J., \& Cloquet, I. (2014). Belgium: Quite a balancing act. European tourism planning and organisation systems: The EU member states. In C. Costa, E. Panyik, \& D. Buhalis (Eds.), Explaining Tourism Governance (pp. 401-417). Bristol: Channel View Publications.

Dredge, D. (2006). Policy networks and the local organisation of tourism. Tourism Management, 27(2), 269-280. http://dx.doi.org/10.1016/j.tourman.2004.10.003.

Go, F. M., \& Govers, R. (2000). Integrated quality management for tourist destinations: A European perspective on achieving competitiveness. Tourism Management, 21(1), 79-88. http://dx.doi.org/10.1016/S0261-5177(99)00098-9.

Gould, R. V., \& Fernandez, R.,M. (1989). Structures of mediation: A formal approach to brokerage in transaction networks. Sociological Methodology, 19, 89-126. http://dx. doi.org/10.2307/270949.

Hall, C. M. (1999). Rethinking collaboration and partnership: A public policy perspective. Journal of Sustainable Tourism, 7(3), 274-289. http://dx.doi.org/10.1080/ 09669589908667340.

Hartman, S. (2016). Towards adaptive tourism areas? A complexity perspective to examine the conditions for adaptive capacity. Journal of Sustainable Tourism, 24(2), 299-314. http://dx.doi.org/10.1080/09669582.2015.1062017.

Jamal, T. B., \& Getz, D. (1995). Collaboration theory and community tourism planning. Annals of Tourism Research, 22(1), 186-204. http://dx.doi.org/10.1016/01607383(94)00067-3.

Keast, R., Mandell, M. P., Brown, K., \& Woolcock, G. (2004). Network structures: Working differently and changing expectations. Public Administration Review, 64(3), 363-371 (10.1111/j.1540-6210.2004.00380.x).

Klijn, E. H., Steijn, B., \& Edelenbos, J. (2010). The impact of network management on outcomes in governance networks. Public Administration, 88(4), 1063-1082. http:// dx.doi.org/10.1111/j.1467-9299.2010.01826.x.

Leiper, N. (1990). Partial industrialization of tourism systems. Annals of Tourism Research, 17(4), 600-605. http://dx.doi.org/10.1016/0160-7383(90)90030-U.

Lemmetyinen, A., \& Go, F. M. (2009). The key capabilities required for managing tourism business networks. Tourism Management, 30(1), 31-40. http://dx.doi.org/10.1016/j. tourman.2008.04.005.

Novelli, M., Schmitz, B., \& Spencer, T. (2006). Networks, clusters and innovation in tourism: A UK experience. Tourism Management, 27(6), 1141-1152. http://dx.doi. org/10.1016/j.tourman.2005.11.011.

Nunkoo, R., \& Ramkissoon, H. (2012). Power, trust, social exchange and community support. Annals of Tourism Research, 39(2), 997-1023. http://dx.doi.org/10.1016/j. annals.2011.11.017.

Pavlovich, K. (2003). The evolution and transformation of a tourism destination network: The Waitomo Caves, New Zealand. Tourism Management, 24(2), 203-216. http://dx. doi.org/10.1016/S0261-5177(02)00056-0.

Pearce, D. G. (2014). Toward an integrative conceptual framework of destinations. Journal of Travel Research, 53(2), 141-153. http://dx.doi.org/10.1177/ 0047287513491334

Petrou, A., Pantziou, E. F., Dimara, E., \& Skuras, D. (2007). Resources and activities complementarities: The role of business networks in the provision of integrated rural tourism. Tourism Geographies, 9(4), 421-440. http://dx.doi.org/10.1080/ 14616680701647634.

Porter, M. E. (1990). Competitive advantage of nations: Creating and sustaining superior performance. New York, NY: Simon and Schuster.

Powell, W. W., Koput, K. W., \& Smith-Doerr, L. (1996). Interorganizational collaboration and the locus of innovation: Networks of learning in biotechnology. Administrative Science Quarterly, 41(1), 116-145. http://dx.doi.org/10.2307/2393988.

Presenza, A., \& Cipollina, M. (2010). Analysing tourism stakeholders networks. Tourism Review, 65(4), 17-30. http://dx.doi.org/10.1108/16605371011093845.

Provan, K. G., \& Kenis, P. (2008). Modes of network governance: Structure, management, and effectiveness. Journal of Public Administration Research and Theory, 18(2), 229-252. http://dx.doi.org/10.1093/jopart/mum015.

Sage, C. (2003). Social embeddedness and relations of regard: Alternative 'good food' 
networks in south-west Ireland. Journal of Rural Studies, 19(1), 47-60. http://dx.doi. org/10.1016/S0743-0167(02)00044-X.

Saxena, G. (2005). Relationships, networks and the learning regions: Case evidence from the Peak District National Park. Tourism Management, 26(2), 277-289. http://dx.doi. org/10.1016/j.tourman.2003.11.013.

Scott, N., Baggio, R., \& Cooper, C. (2008). Network analysis and tourism: From theory to practice. Clevedon: Channel View Publications.

Sheehan, L., Ritchie, J. R. B., \& Hudson, S. (2007). The destination promotion triad: Understanding asymmetric stakeholder interdependencies among the city, hotels, and DMO. Journal of Travel Research, 46(1), 64-74. http://dx.doi.org/10.1177/ 0047287507302383.

Sørensen, F. (2007). The geographies of social networks and innovation in tourism. Tourism Geographies: An International Journal of Tourism Space, Place and Environment, 9(1), 22-48. http://dx.doi.org/10.1080/14616680601092857.

Stein, S. M., \& Harper, T. L. (2003). Power, trust, and planning. Journal of Planning Education and Research, 23(2), 125-139. http://dx.doi.org/10.1177/ 0739456 X03258636.

Stoffelen, A., \& Vanneste, D. (2016). Institutional (dis)integration and regional development implications of whisky tourism in Speyside, Scotland. Scandinavian Journal of Hospitality and Tourism, 16(1), 42-60. http://dx.doi.org/10.1080/15022250.2015. 1062416.

Timur, S., \& Getz, D. (2008). A network perspective on managing stakeholders for sustainable urban tourism. International Journal of Contemporary Hospitality Management, 20(4), 445-461. http://dx.doi.org/10.1108/09596110810873543. van der Zee, E., \& Vanneste, D. (2015). Tourism networks unravelled; A review of the literature on networks in tourism management studies. Tourism Management Perspectives, 15, 46-56. http://dx.doi.org/10.1016/j.tmp.2015.03.006.

Viren, P. P., Vogt, C. A., Kline, C., Rummel, A. M., \& Tsao, J. (2015). Social network participation and coverage by tourism industry sector. Journal of Destination Marketing \& Management, 4(2), 110-119. http://dx.doi.org/10.1016/j.jdmm.2015. 03.004 .

Volgger, M., \& Pechlaner, H. (2014). Requirements for destination management organizations in destination governance: Understanding DMO success. Tourism Management, 41, 64-75. http://dx.doi.org/10.1016/j.tourman.2013.09.001.

Volgger, M., \& Pechlaner, H. (2015). Governing networks in tourism: What have we achieved, what is still to be done and learned? Tourism Review, 70(4), 298-312. http://dx.doi.org/10.1108/TR-04-2015-0013.

Wasserman, S., \& Faust, K. (1994). Social network analysis: Methods and applications, 8. Cambridge: Cambridge University Press.

Zach, F., \& Racherla, P. (2011). Assessing the value of collaborations in tourism networks: A case study of Elkhart County, Indiana. Journal of Travel \& Tourism Marketing, 28(1), 97-110. http://dx.doi.org/10.1080/10548408.2011.535446.

Zehrer, A., \& Raich, F. (2010). Applying a lifecycle perspective to explain tourism network development. The Service Industries Journal, 30(10), 1683-1705. http://dx.doi. org/10.1080/02642060903580698.

Zehrer, A., Raich, F., Siller, H., \& Tschiderer, F. (2014). Leadership networks in destinations. Tourism Review, 69(1), 59-73. http://dx.doi.org/10.1108/TR-06-2013-0037. 